UDC 681.2:532.64

DOI: 10.15587/2706-5448.2021.225212

Article type «Reports on Research Projects»

\section{Volodymyr Doroshenko, Oleksandr Titlov, Ivan Kuper}

\title{
DEVELOPMENT OF TECHNOLOGY OF GAS CONDENSATE EXTRACTION FROM THE FORMATION IN THE CONDITIONS OF RETROGRADE CONDENSATION
}

The object of research is gas condensate fields at a late stage of their development under conditions of a decrease in reservoir pressure below the pressure of condensate separation from a gaseous state. Reservoir losses of condensate during the development of deposits in depletion mode can reach $78 \%$, which entails the need to use various methods of stimulating the reservoir system to remove it. The most acceptable method is the use of a cycling process by re-injection (recirculation) of the produced and separated gas into the formation. A significant disadvantage of the cycling process is the long-term conservation of gas reserves as a result of its re-injection into the reservoir and significant capital and operating costs for dry gas injection. From a technological point of view, the use of the cycling process is constrained by the low value of the sweep efficiency. Dry gas that is injected has a lower viscosity in terms of the gas-condensate mixture is withdrawn from the reservoir, and under the conditions of the heterogeneous structure of the reservoir, its rapid breakthrough from injection to production wells takes place and, as a result, a decrease in the efficiency of condensate recovery. As an alternative to the cycling process for extracting retrograde condensate from the reservoir, it has been proposed to squeeze it out with water.

The paper proposes a unified waterflooding system, actually displacing condensate with water or a gas-water mixture. This is achieved by controlled operation of injection and production wells. First, gas is taken from the wells, and with the appearance of water in the product, methods of intensifying the transfer to the surface are used. If necessary, the wells are switched to forced production mode. The results of laboratory studies carried out on real samples of core material from the Andriyashivske gas condensate field (Ukraine) are presented. The directions of the implementation of gas-water repression in gas condensate fields with the parallel use of restrained reservoir gas available in the reservoir are substantiated. The technology allows to extract up to $50 \%$ of the condensate dropped out in the reservoir.

Keywords: gas condensate fields, retrograde condensate, cycling process, unified waterflooding system, gaswater repression.

\section{Introduction}

Gas condensate fields, like purely gas fields, are developed mainly in the regime of depletion of reservoir energy. Development of depleted fields is carried out, as a rule, at pressures significantly lower than the pressure of the onset of condensation of the formation mixture and is characterized by the formation of significant residual volumes of retrograde condensate. The condensate becomes practically immobile due to its low phase permeability. With the initial content of heavy hydrocarbons in the gas up to $300-600 \mathrm{~g} / \mathrm{m}^{3}$, the saturation of the formation pores with condensate that has fallen out of the gas, as a rule, does not exceed 10-20\% and in most cases is below the critical (equilibrium) value at which it becomes mobile [1,2]. The movement of condensate partially occurs only in the bottomhole formation zones of limited size, in fact, within the radius of the depression funnel. At the same time, the action of capillary and gravitational forces during depletion of the state causes the formation of a man-made condensate rim in the reservoir [3]. The results of laboratory, analytical and industrial studies indicate that the retrograde condensation of a hydrocarbon mixture has a negative effect on almost all technological processes of both condensate and gas production. Reservoir condensate losses during the development of gas condensate fields in the depletion mode are on average $60-78 \%$ [4], and for other researches - 40-70\% [5], which is consistent.

The saturation of the collector with condensate, as a rule, is much lower than the critical values of saturation of the collector-side phase given its mobility.

These phenomena, combined with the low energy characteristics of the formation, cause significant barriers to the withdrawal of residual reserves of retrograde condensate to the surface.

Distinguish between passive and active ways of developing gas condensate fields. Passive methods are based on the gradual depletion of the reservoir energy, which affects it only by changing the technological modes of production wells. Active methods provide for maintaining the energy 
of the formation by acting on the formation system through a network of injection and production wells, providing an increase in condensate production by $15-20 \%$ [6]. In this case, the field is being developed for depletion for some time, and then a working agent is injected in the reservoir to maintain or raise the formation pressure values (nonhydrocarbon gases, mixtures thereof, water, water with gas).

An acceptable method for recovering condensate precipitated in the reservoir is the cycling process [7, 8], which is implemented by reverse injection into the reservoir (recirculation) of the produced and separated gas. The efficiency of dry gas injection depends on the available gas and condensate reserves, the specific content of condensate in the gas, the type and nature of the phase diagram, the number of production and injection wells, their operating modes and their location on the structure and gas-bearing area. Undoubtedly, the cycling process provides an increase in condensate performance, but at the same time it is characterized by long-term conservation of gas reserves as a result of its re-injection into the formation and significant capital and operating costs for dry gas injection. Therefore, the cycling process has been implemented only at 26 fields in the USA and at 2 in Ukraine.

An alternative to the reverse injection of dry hydrocarbon gas into the formation can be artificial flooding of gas condensate deposits [9]. The essence of the method is to inject water into the reservoir in order to maintain the reservoir pressure above the pressure of the beginning of condensation. However, this method has not received widespread use, given the possible breakthrough of water in producing wells and watering of the reservoir sections saturated with a gas-condensate mixture with a possible entrapment of gas and a decrease in its recovery factor [10]. The amount of restrained gas depends on a number of geological and physical factors, such as porosity, permeability, reservoir heterogeneity, rate and uniformity of gas extraction over the area by the reservoir thickness. In addition, according to industrial data [11], the extrusion of retrograde condensate from a porous medium by water leads to an increase in its molecular weight, density, and viscosity.

Consequently, with all the positive and negative features, waterflooding is one of the promising directions for increasing the hydrocarbon production during the development of gas condensate deposits in conditions of retrograde condensation [12]. The idea of injecting water into a gas condensate reservoir to squeeze out liquid condensate is not new [4, 5, 13], but remains controversial. On the one hand, it attracts by the relative ease of implementation, and on the other hand, it is alarming about possible losses of gas and condensate in the formation. Recently, gas condensate deposits have been discovered at depths of more than $3000 \mathrm{~m}$ with a high condensate-gas ratio and a high density of the formation fluid. For such reservoirs, the use of waterflooding technology is becoming a more attractive method to increase the condensate ratio of study. Therefore, studies aimed at studying the processes and developing technological methods for extracting retrograde condensate from the reservoir remain relevant and have both theoretical and applied significance.

Thus, the object of research is selected gas condensate fields at a late stage of their development under conditions of a decrease in reservoir pressure below the pressure of condensate separation from a gaseous state. And the aim of research is to develop technological methods for extracting retrograde condensate that precipitated in the reservoir during the development of the field and the prospect of using water-gas repression with the use of restrained reservoir gas.

\section{Methods of research}

The study was carried out at the theoretical (grouping and analysis of information sources) and experimental levels using a standard installation for studying rock samples (cores) in conditions close to real in terms of reservoir pressures and temperatures. In the course of research [14] on real cores of the Andriyashivske gas condensate field (Ukraine), a series of experiments was carried out aimed at studying the process of squeezing out condensate by creating a water-gas repression both with the previous injection of the hydrocarbon border and without it.

The reservoir model (core) was filled with water under vacuum and purged with nitrogen. After the creation of residual water saturation, the model was evacuated and saturated with stable condensate, which later turned into unstable (raw) condensate. After saturation of the porous medium with condensate, nitrogen is replaced by natural gas. Further, the gas-condensate mixture was flooded with formation water - a solution of sodium chloride mineralization $100 \mathrm{~kg} / \mathrm{m}^{3}$. The gas-liquid mixed outlet from the model was separated to measure the volumes of its ingredients. Thus, the coefficient of residual condensate saturation was determined and the coefficient of squeezing out condensate with water both at the moment of water breakthrough from the model and after its prolonged flushing until the completion of the removal of condensate. The saturation of the porous medium with individual phases was determined by their balance ratio.

At the second stage of the research, before the injection of the gas-condensate mixture, the model was filled with raw condensate, which whirled while at the exit from the model, its parameters acquired initial values at the input to the model. For this, gas condensate mixture was pumped through the model at a pressure of $30 \mathrm{MPa}$ and a temperature of $90{ }^{\circ} \mathrm{C}$. Thus, in the process of research, the reservoir model was filled with gas, residual water and condensate, which simulated conditions close to real.

\section{Research results and their discussion}

It is known that in a real pore space, a complex multiphase system is filtered, and when liquid condensate is squeezed out by gas or water, interphase mass transfers take place, as a result of which the properties of the liquid phase and the content of condensate in the gas can change. However, at the first stage, the pre-lingering processes were not taken into account; they can be estimated only by complex calculations using the equations of multicomponent filtration.

Experimental studies of the processes of squeezing out a gas-condensate mixture with water were carried out on a core at a pressure of $30 \mathrm{MPa}$ and a temperature of $90{ }^{\circ} \mathrm{C}$. Gas extrusion coefficients $K_{\text {ex.g }}$ and condensate $K_{c . g}$. were determined by the balance method:

$$
\begin{aligned}
& K_{\text {ex.g. }}=\frac{Q_{g e x}-Q_{c e x} \cdot S}{V_{\text {mod }}-j \cdot \rho_{g}(1-S q)}, \\
& K_{\text {ex... }}=\frac{\left(Q_{\text {eex }}-Q_{g e x} q\right) \beta}{V_{\text {mod }} \cdot \rho_{c}(1-S q)},
\end{aligned}
$$


where $Q_{g \text { ex }}, Q_{\text {cex }}$ - gas and condensate extracted from the model under standard conditions, $\mathrm{cm}^{3} ; S$ - gas saturation of reservoir condensate, unit fraction; $V_{\bmod }$ - pore volume of the model, $\mathrm{cm}^{3} ; j$ - reciprocal of the gas volumetric coefficient; $\rho_{g}, \rho_{c}-$ saturation with gas, condensate, unit fraction; $\beta$ - volumetric coefficient of formation condensate, unit fraction; $q$ - content of condensate in the gas produced, $\mathrm{g} / \mathrm{cm}^{3}$.

Experimental studies were carried out in three directions:

1) squeezing out condensate with water;

2) squeezing out condensate by the cyclic injection method;

3) extrusion according to the water-gas scheme.

Fig. 1 shows the results of condensate squeezing out with distilled water. In order to increase the residual condensate saturation (creation of a movable condensate shaft), $10 \%$ of the pore volume was injected before flooding. As can be seen, the condensation rate was only $4 \%$ (Fig. 1, line 1). So, the usual waterflooding of gas condensate fields, even with the previous injection of hydrocarbons, is ineffective.

To study the combined action of water and gas (water-gas repression), the experiment was continued (Fig. 1, line 2). As it is possible to see, the water-gas repression can significantly increase the recovery rate of retrograde condensate, even after conventional waterflooding (the condensate squeezing out coefficient reached $43 \%$ ).

In the next experiment (Fig. 1, line 3) water-gas repression began immediately after injection of $10 \%$ of the condensate rim. The generalized results of this series of studies indicate that this approach provides an increase in the coefficient of squeezing out of retrograde condensate up to $80 \%$.

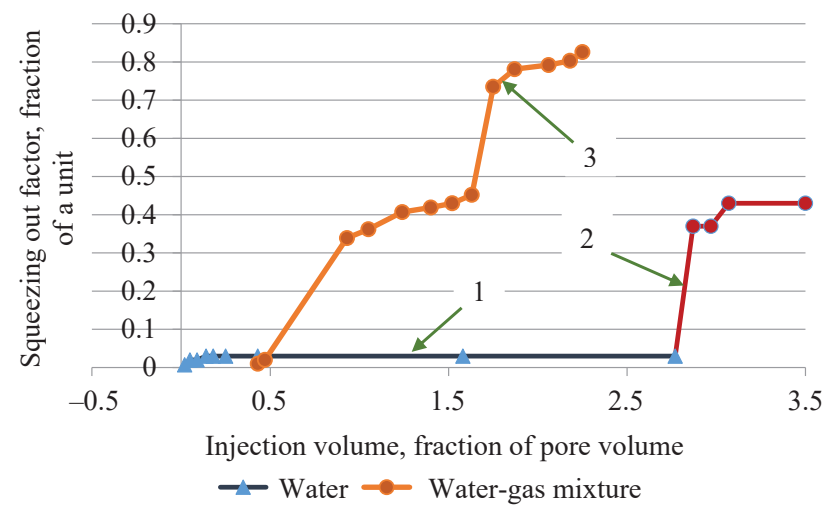

Fig. 1. Squeezing out of condensate from the gas condensate model: 1 - water; 2 - after by water-gas mixture; 3 - water-gas mixture without prior injection of water

Injections of hydrocarbon solvent, water-gas mixtures, surfactant solution and sequential injection of an aqueous solution of surfactant and gas in front of the water front increase the coefficient of condensate squezzing out compared to the injection of water alone. Thus, in [15] the development of a gas condensate deposit, operated in conditions of lower formation pressure below the condensing pressure, is proposed to be carried out by injecting a border of liquid hydrocarbons (hydrocarbon condensate, light oil), which are pushed simultaneously or alternately by hydrocarbons. In this case, the volume of products is selected from the reservoir, must be at least three times the volume of reagents pumped into the reservoir.
Since the implementation of water and gas repression requires, as well as the cycling process, a significant amount of gas and appropriate equipment, the possibility of extracting retrograde condensate from the depleted formation using the available gas in the reservoir was also considered [16]. In this case, the condensate was first displaced by water, and then, to break the water from the model, the system was degassed, reducing the pressure by $25 \%$ below the pressure of the onset of condensate and again continued to squeeze the condensate with water (Fig. 2).



Fig. 2. Squeezing out condensate with water (until water breakthrough), reducing the pressure to 0.25 of the condensation pressure and further squeezing out with water

The architecture of the experiment is based on the permanent squeezing out of retrograde condensate with water, stopping the squeezing out and cleaning the system with activation of the restrained gas and the continuation of water injection. Such a procedure (Fig. 2) makes it possible to extract about $14 \%$ of retrograde condensate by the action of restrained formation gas and $30 \%$ by further water injection.

\section{Conclusions}

Analytical (survey) and experimental studies have been performed that indicate the feasibility of using water-gas repression using gas in the field. This allows to remove up to $50 \%$ of the condensate precipitated in the formation. At the same time, to ensure the mobility of condensate, it is advisable to inject a condensate rim in the amount of $2-3 \%$ of the volume of the reservoir pore space before the start of the water-gas repression.

\section{References}

1. Zakirov, S. N. (1998). Razrabotka gazovykh, gazokondensatnykh i neftegazo-kondensatnykh mestorozhdenii. Moscow: Struna, 628.

2. Kondrat, R. M. (1992). Gazokondensatootdacha plastov. Moscow: Nedra, 253.

3. Kashuba, A. V. (2011). O vozmozhnosti obrazovaniia tekhnogennoi otorochki retrogradnogo kondensata pri razrabotke gazokondensatnykh zalezhei. Vestnik $O G U, 16$ (135), 52-54.

4. Zakirov, S. N. (1989). Teoriia i proektirovanie razrabotki gazovykh $i$ gazokondensatnykh mestorozhdenii. Moscow: Nedra, 330.

5. Tekhnicheskii seminar obschestva inzhenerov neftianikov «Kondensatootdacha gazokondensatnykh mestorozhdenii» (2008). SPE Society of Petroleum Engineers. Moscow.

6. Zakirov, S. N., Kondrat, R. M. (1990). Aktivnoe vozdeistvie na protsess razrabotki mestorozhdenii prirodnykh gazov s tseliu povysheniia uglevodorodootdachi plastov. Razrabotka gazokondensatnykh mestorozhdenii. Sektsiia 3 - Razrabotka neftegazokondensatnykh mestorozhdenii. Krasnodar, 24-28. 
7. Iunusova, L. V., Volkov, A. N., Pankratova, E. I., Morev, A. I. (2012). Razrabotka meropriiatii po povysheniiu effektivnosti tekhnologii aktivnogo vozdeistviia na plast na Vuktylskom NGKM. Gazovaia promyshlennost, 5, 29-32.

8. Uliashev, V. E., Popon, A. A., Dementev, D. A. (2005). Otsenka vozmozhnosti doizvlecheniia retrogradnogo kondensata iz obvodnennogo plasta putem prokachki «sukhogo» gaza. Nauchnye problemy $i$ perspektivy neftegazovoi otrasli v Severo-Zapadnom regione Rossii: Ch. 2. Razrabotka i ekspluatatsiia mestorozhdenii. Kompleksnye issledovaniia plastov i skvazhin. Ukhta, 184-194, $222-223$.

9. Agarwal, R. G., Al-Hussainy, R., Ramey, H. J. (1965). The Importance of Water Influx in Gas Reservoirs. Journal of Petroleum Technology, 17 (11), 1336-1342. doi: http://doi.org/ 10.2118/1244-pa

10. Lutes, J. L., Chiang, C. P., Rossen, R. H., Brady, M. M. (1977). Accelerated Blowdown of a Strong Water-Drive Gas Reservoir Journal of Petroleum Technology, 29 (12), 1533-1538. doi: http:// doi.org/10.2118/6166-pa

11. Shirkovskii, A. I. (1979). Razrabotka i ekspluatatsiia gazovykh $i$ gazokondensatnykh mestorozhdenii. Moscow: Nedra, 300.

12. Rivas-Gomes, S. (1984). Rukovoditel laboratorii fiziki plasta kompanii «Pemeks», Meksika. Zavodpenie gazokondensatnykh plastov. Neft $i$ gaz za rubezhem, 4, 16-22.

13. Burachok, O. V. (2007). Doslidzhennia mozhlyvosti vytisnennia vodoiu kondensatu, shcho vypav u plasti. Naftova $i$ hazova promyslovist, 2, 29-32.

14. Bikman, Ye. S., Hnyp, M. P., Doroshenko, V. M. et. al. (2004). Perspektyvy pidvyshchennia vuhlevodneviddachi Andriiashivskoho HKR. Nafta i haz Ukrainy - 2004. Lviv: Tsentr Yevropy, 2, 19-21.
15. Hnyp, M. P., Prokopiv, V. Y., Doroshenko, V. M., Tarabarynov, P. V., Mykhailiuk, V. D. (2006). Pat. No. 76353 UA. Sposib rozrobky hazokondensatnoho rodovyshcha. MPK: E21B 43/18, E21B 43/16. No. 2004 1109445. declareted: 17.11.2004; published: 17.07.2006, Bul. No. 7.

16. Uliashev, V. E., Burakov, Iu. G., Melentev, G. Ia., Dementev, D. A., Chuprov, V. F. (2005). Eksperimentalnye issledovaniia po izvlecheniiu retrogradnogo kondensata iz obvodnennogo plasta $\mathrm{s}$ ispolzovaniem zaschemlennogo gaza. Nauchnye problemy $i$ perspektivy neftegazovoi otrasli v Severo-Zapadnom regione Rossii. Ch. 2. Razrabotka i ekspluatatsiia mestorozhdenii. Kompleksnye issledovaniia plastov i skvazhin. Ukhta, 194-213, 223.

Volodymyr Doroshenko, Doctor of Technical Sciences, Professor, Department of Oil and Gas Technologies, Engineering and Heat Power Engineering, Odessa National Academy of Food Technologies, Odessa, Ukraine, e-mail: doroshenkovm444@gmail.com, ORCID: http://orcid.org/0000-0003-3408-6124

Oleksandr Titlov, Doctor of Technical Sciences, Professor, Head of Department of Oil and Gas Technologies, Engineering and Heat Power Engineering, Odessa National Academy of Food Technologies, Odessa, Ukraine, e-mail: titlov1959@gmail.com, ORCID: http:// orcid.org/0000-0003-1908-5713

Ivan Kuper, PhD, Associate Professor, Department of Oil and Gas Production, Ivano-Frankivsk National Technical University of Oil and Gas, Ivano-Frankivsk, Ukraine,e-mail: ivankuper@ukr.net, ORCID: http://orcid.org/0000-0003-1058-1382 